\title{
Influence of Cervical Preflaring on Determination of Apical File Size in Maxillary Molars: SEM Analysis
}

\author{
José Roberto VANNI ${ }^{1}$ \\ Roberto SANTOS ${ }^{1}$ \\ Orlando LIMONGI ${ }^{2}$ \\ Danilo M. Zanello GUERISOLI ${ }^{3}$ \\ Alexandre CAPELLI ${ }^{3}$ \\ Jesus Djalma PÉCORA ${ }^{3}$
}

\author{
${ }^{1}$ Faculty of Dentistry, University of Passo Fundo (FOUPF), Passo Fundo, RS, Brazil \\ ${ }^{2}$ School of Dentistry, Lutheran University of Brazil (ULBRA), Canoas, RS, Brazil \\ ${ }^{3}$ Department of Restorative Dentistry, Faculty of Dentistry of Ribeirão Preto, \\ University of São Paulo, Ribeirão Preto, SP, Brazil
}

\begin{abstract}
The purpose of this study was to investigate the influence of cervical preflaring on determination of the initial apical file in mesiobuccal roots of maxillary molars. Fifty first molars with degree of curvature of the mesiobuccal root between $10^{\circ}$ and $15^{\circ}$ were utilized. After standard access opening and removal of pulp tissue, the working length (WL) was determined at $1 \mathrm{~mm}$ from the root apex. Five groups $(n=10)$ were formed at random, according to the type of cervical preflaring performed. In group 1, the size of the initial apical file was determined without cervical preflaring. In groups 2 to 5 , the cervical and middle thirds of the canals were preflared with Gates-Glidden drills, K3 Orifice Opener instruments, ProTaper instruments and LA Axxess burs, respectively. Canals were sized manually with Kfiles, starting with size $08 \mathrm{~K}$-files, inserted passively up to the WL. File sizes were increased until a binding sensation was felt at the WL and the size of the file was recorded. The binding instruments were fixed into the canals at the WL with methylcyanacrylate. Crosssections of the WL region were examined under scanning electron microscopy and the discrepancies between the canal diameter and the diameter of first file to bind at the WL were calculated using UTHSCSA ImageTool software. Data were analyzed statistically by ANOVA and multiple comparisons were done by Tukey's HSD post-hoc test. Significant differences $(\mathrm{p}<0.001)$ were found among the groups. The major discrepancy was observed for the group without preflaring (mean $0.1543 \mathrm{~mm} \pm 0.0216$ ). Cervical preflaring with LA Axxess burs produced the least discrepancies between the canal size and the diameter of the initial apical instrument (mean $0.026 \mathrm{~mm}$ \pm 0.0037 ), followed by ProTaper files (mean $0.0567 \mathrm{~mm} \pm 0.0354$ ). Canals preflared with Gates-Glidden drills and K3 Orifice Opener instruments showed statistically similar discrepancy results to each other ( $\mathrm{p}>0.05$ ) (means $0.1167 \mathrm{~mm} \pm 0.0231 \mathrm{and} 0.1313 \mathrm{~mm} \pm$ 0.0344 , respectively). In conclusion, preflaring of the cervical and middle thirds improved the determination of the initial apical instrument. Canals preflared with LA Axxess burs showed a more accurate binding of the files to the anatomical diameter at the WL in the mesiobuccal roots of maxillary first molars.
\end{abstract}

Key Words: cervical preflaring, initial apical file, anatomic diameter.

\section{INTRODUCTION}

During biomechanical preparation, the anatomic diameter of the root canal is determined by recording the size of the file that first binds within the canal walls at the working length (WL). Some authors suggest that the amount of apical enlargement to be achieved during canal shaping should be based on determination of the initial apical diameter and performed using three file sizes greater than the first file that fits at the apex (1-4).

The determination of the anatomic diameter of root canals is of paramount importance because it allows a more reliable establishment of the most adequate file to initiate biomechanical preparation and enlarge the 
intracanal space. Moreover, in addition to be associated to shaping, determination of the anatomic diameter is also related to cleaning of the root canal system (5).

The detection of the apical constriction and determination of the size of the first file that binds at WL are based on the operator's tactile sensitivity. This premise relies on the assumptions that the root canal is narrower in its apical third and that the file would pass without interference until reaching this constriction, which offers resistance to further penetration (6).

Nevertheless, it has been reported that continuous and progressive dentin formation within the pulp space narrows the root canal diameter, mainly at the cervical third (7). Therefore, an instrument may be equivocally chosen to initiate instrumentation due to inaccurate determination of the real anatomical diameter, in cases in which the binding sensation felt by the operator actually resulted from unappreciated engagement of the file at the canal entrance rather than from binding at the working length (8).

Preflaring of the cervical and middle thirds of the root canal and elimination of interferences in these regions allow for a more accurate assessment of the real anatomical diameter of the apical constriction and more reliable determination of the initial apical file (8-12).

The purpose of this study was to investigate the influence of cervical preflaring with different rotary instruments on the determination of the initial apical file in mesiobuccal roots of maxillary first molars.

\section{MATERIAL AND METHODS}

Fifty human maxillary first molars with complete root formation, obtained from stock of the Endodontics Research Laboratory of the Faculty of Dentistry of Ribeirão Preto, University of São Paulo, were used in this study. The teeth were kept in $0.1 \%$ thymol solution at $9^{\circ} \mathrm{C}$, from where they were taken $24 \mathrm{~h}$ before use, and placed under running water to eliminate traces of thymol. The curvature of the mesiobuccal root was measured using the method suggested by Schneider (13) and should range between $10^{\circ}$ and $15^{\circ}$.

Standard access to pulp chamber was gained and the samples were immersed in $5.25 \%$ sodium hypochlorite under vacuum for $15 \mathrm{~min}$ to dissolve pulp remnants from the canals. Teeth were washed and irrigated with distilled water to eliminate sodium hypochlorite residues, and the mesiobuccal canal of each tooth was explored with a size 06 K-file (Dentsply/Maillefer, Ballaigues, Switzerland) until the apical foramen was reached and the tip of the file was visible. The real canal length was determined and the working length was established at 1 $\mathrm{mm}$ from root apex.

Teeth were randomly assigned to five groups $(n=10)$. In Group 1, the size of the initial apical file was determined without previous cervical preflaring of the mesiobuccal root canal. Group 2 had the cervical and middle thirds of the mesiobuccal root canal enlarged with Gates-Glidden drills sizes 90 and 110 (Dentsply/ Maillefer). The length of this preflaring was determined by the resistance felt in the middle portion of the canal. Group 3 had the cervical and middle thirds of the mesiobuccal root canal enlarged with nickel-titanium $\mathrm{K}^{3}$ Orifice Opener instruments sizes 25/.08 and 25/.10 (SybronEndo, Glendora, CA, USA), $5 \mathrm{~mm}$ short of the working length. ProTaper SX and S1 instruments (Dentsply/Maillefer) were used $5 \mathrm{~mm}$ short of the working length to enlarge the cervical and middle thirds of mesiobuccal root in Group 4. Titanium-nitrite treated, stainless steel LA Axxess burs (SybronEndo) sizes 20/ .06 and 35/.06 were used for preflaring the cervical and middle thirds of root canals in Group 5, until resistance was felt in the middle portion of the canal.

$\mathrm{K}^{3}$ Orifice Openers and ProTaper instruments were used at $300 \mathrm{rpm}$, while Gates-Glidden and Axxess burs were used at 10,000 rpm. Irrigation with $2 \mathrm{~mL}$ of $1 \%$ sodium hypochlorite was performed between instruments during preflaring of all canals, with a final flush of $5 \mathrm{~mL}$ of this solution. A final irrigation with 10 $\mathrm{mL}$ of distilled, deionized water was done. The irrigating solutions were delivered with blunt tip, 31 gauge EndoEze irrigation needles (Ultradent Products Inc., South Jordan, UT, USA).

Root canals were sized using manual K-files (Dentsply/Maillefer), starting with size 08 files, inserted passively until the WL was reached. File sizes progressively increased until obtaining an instrument that bound at the WL (initial apical file), and the size of the instrument was recorded for each tooth. The handles of the files had been painted in black to avoid identification, in such a way that the operator was unaware of the file size used until a binding sensation was felt at the WL.

After apical file size determination, the binding instruments were fixed into the canals at the $\mathrm{WL}$ with methylcyanacrylate. The teeth were then sectioned 
transversally $1 \mathrm{~mm}$ from the apex, with the binding file in position. The apical region was observed under scanning electron microscopy at X100 magnification and the images were recorded digitally.

The analysis of the images obtained was performed on a computer using the free UTHSCSA ImageTool software (developed at the University of Texas Health Science Center at San Antonio, Texas, USA and available from the Internet by anonymous FTP from ftp://maxrad6.uthscsa.edu). The diameter of the root canal at the WL and the diameter of the initial apical file were measured for each specimen. The discrepancy between these diameters was calculated and the results of each group were submitted to statistical analysis. The measurements corresponding to the anatomical diameters of the root canals were also analyzed statistically.

Data were submitted to one-way ANOVA to assess the effect of the preflaring techniques on the discrepancies found between the diameter of the binding instruments and the anatomic diameter of root canals. Statistical analysis was performed at 0.05 significance level, using the GraphPad Prism version 4.00 for Windows (GraphPad Software, San Diego California USA), which is available at the website address www.graphpad.com.

\section{RESULTS}

Statistical analysis revealed no significant differences ( $p>0.05)$ among the anatomical diameters of the root canals at the working length, which indicates that the specimens were drawn from the same population and validates the experimental model.

Discrepancies between the canal diameter and the diameter of the initial apical file in each group are given in Table 1. Analysis of variance revealed statistically significant differences $(\mathrm{p}<0.001)$ among groups with

Table 1. Discrepancies ( $\mathrm{mm}$ ) between the diameters of the binding files and canals at the working length, for the different groups

\begin{tabular}{lr}
\hline Preflaring technique & Mean \pm SD \\
\hline No preflaring & $0.1543 \pm 0.0216$ \\
Gates-Glidden drills & $0.1167 \pm 0.0231$ \\
K$^{3}$ Orifice Openers & $0.1313 \pm 0.0344$ \\
ProTaper instruments & $0.0567 \pm 0.0354$ \\
Axxess burs & $0.0026 \pm 0.0037$ \\
\hline
\end{tabular}

respect to discrepancies between anatomical diameter and the size of the first file to bind at the working length. Post-hoc comparisons among the groups were done with Tukey's HSD post-hoc test.

The greatest discrepancy was found in Group 1 (no preflaring) (Fig. 1). Gates-Glidden drills and $\mathrm{K}^{3}$ Orifice Opener instruments showed no statistically significant differences $(\mathrm{p}>0.05)$ between their results (Figs. 2 and 3). ProTaper files had lesser discrepancy values than Gates-Glidden drills and K3 Orifice Openers and greater discrepancy than LA Axxess burs (Fig. 4). LA Axxess burs produced the least differences between the anatomical diameter and the diameter of the initial apical instrument (Fig. 5).

\section{DISCUSSION}

Apical instrumentation is one of the most critical aspects of endodontic treatment, mainly in curved canals. Studies aimed at establishing more adequate parameters for biomechanical preparation of the apical third have stated a relationship between cervical preflaring of root canals and more accurate determination of the initial apical file $(5,8,9,11,12,14,15)$.

The findings of this study revealed that when the cervical third was not preflared, the determination of the initial apical file did not reflect the real apical anatomic diameter. The group without cervical preflaring presented the greatest discrepancies between the canal size and the diameter of the file that bound at the WL (mean 0.1543 $\mathrm{mm}$ ), when compared to the other experimental groups.

As the cervical interferences were eliminated, files of greater sizes could be passively introduced into the canals until obtaining an instrument that bound at the working length, which resulted in lesser discrepancy between the size of the binding file and the anatomic diameter at the WL. The greater the removal of cervical interferences, the lesser the discrepancy between the canal diameter and the diameter of the binding file. These results are consistent with those of previous studies using similar methodology $(11,12)$.

From all specimens evaluated, the root canals preflared with LA Axxess system presented the least discrepancies between the canal size and the diameter of the first file that bound at the working length. This may possibly be attributed to characteristics of the LA Axxess system, which include the configuration, metal alloy properties and mode of operation. Additionally, the 


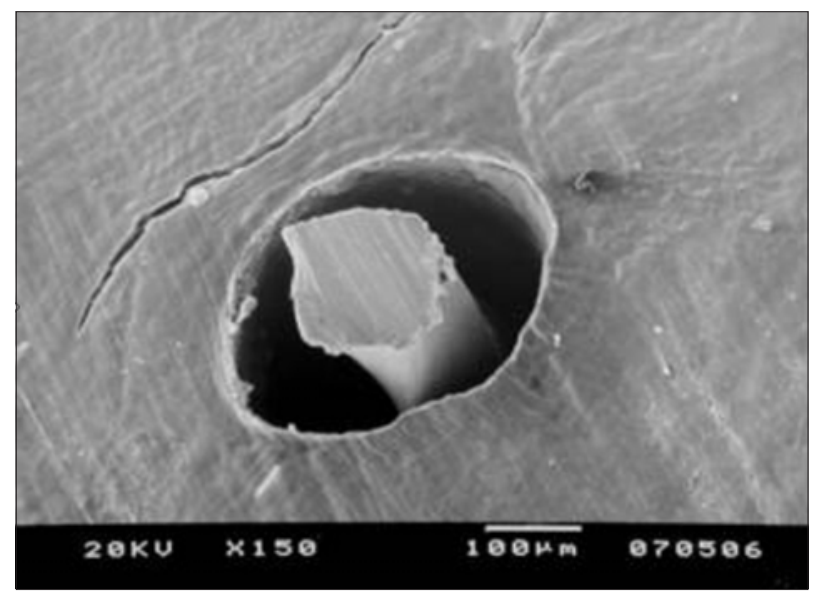

Figure 1. SEM micrograph of Group 1 (no preflaring). Transverse section at the working length.

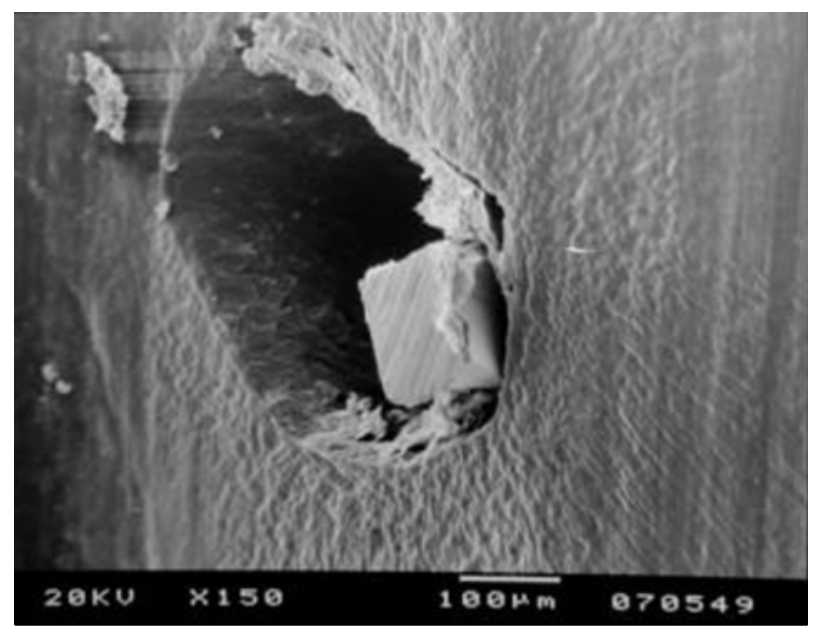

Figure 3. SEM micrograph of Group 3 (preflaring with $\mathrm{k}^{3}$ Orifice Openers). Transverse section at the working length.

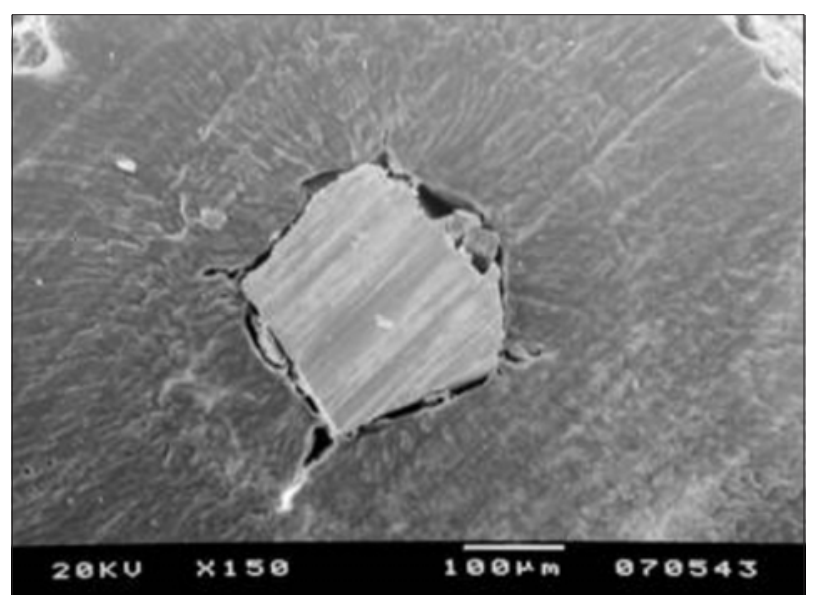

Figure 5. SEM micrograph of Group 5 (preflaring with LA Axxess burs). Transverse section at the working length.

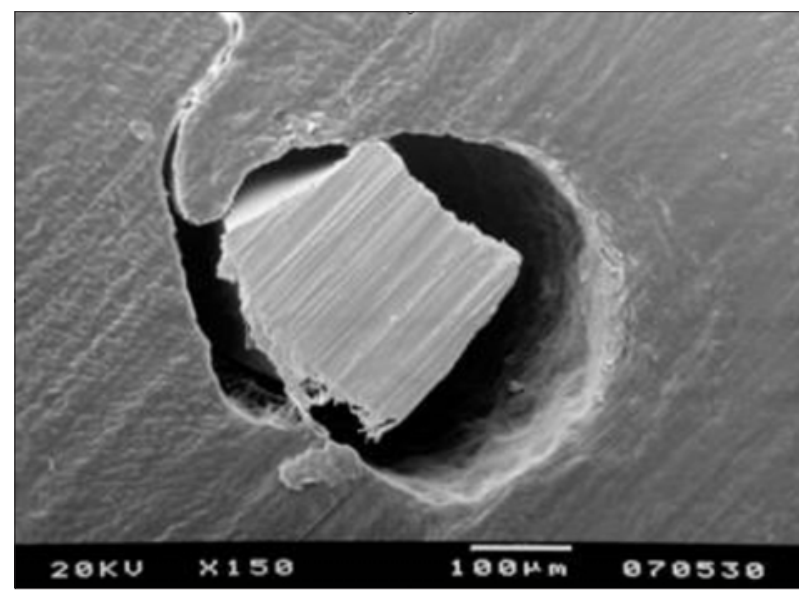

Figure 2. SEM micrograph of Group 2 (preflaring with GatesGlidden drills). Transverse section at the working length.

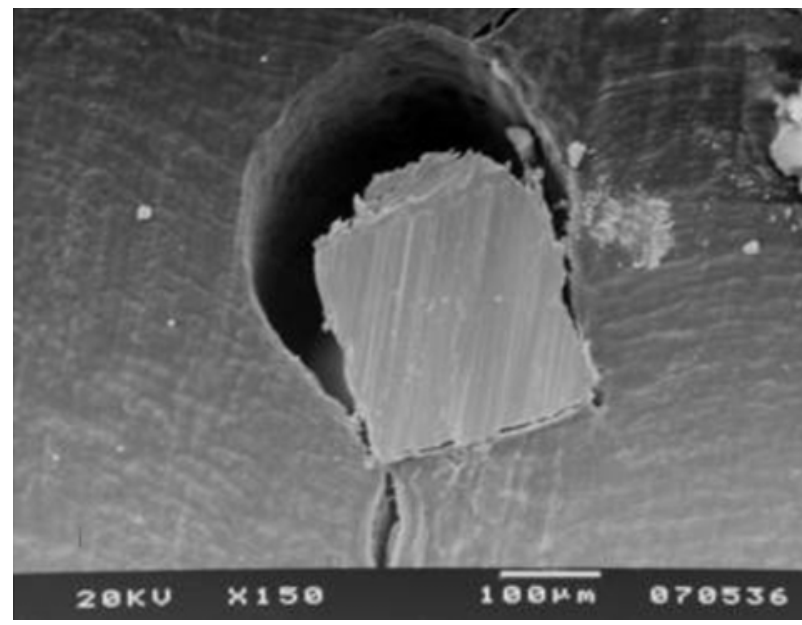

Figure 4. SEM micrograph of Group 4 (preflaring with Protaper SX and S1 files). Transverse section at the working length.

taper (0.06), safe-end and flute design of LA Axxess instruments have been shown to yield complete removal of cervical interferences without occurrence of deviation or perforations (11).

The group preflared with ProTaper (S1, SX) instruments was the second best, i.e., presented the least discrepancy between the canal and file diameters, after the LA Axxess system. The good performance of ProTaper files is due to their modified design that provides optimal cutting efficiency and also to the multiple tapers along the active tip of the files, which allow for greater removal of interferences in the cervical third (16).

The Gates-Glidden drills provided direct access to both cervical and middle thirds of root canals, 
reducing the contact area of the instrument in these regions. Nevertheless, these instruments, as well as the Orifice Opener NiTi files did not allow for accurate determination of the initial apical file. These findings are in agreement with those of previous studies $(8,10-12)$.

In some cases, size $10 \mathrm{~K}$-files are determined as the initial apical file in mesiobuccal roots of maxillary molars because the accentuated curvature of the root narrows the canal diameter (17). In the present investigation, the degree of curvature of the mesiobuccal root was standardized in all teeth to avoid that the root curvature could be considered as an additional variable interfering with the discrepancies found between the diameters of the canal and the initial apical file, which would directly affect the reliability of the study outcomes.

Size $30 \mathrm{~K}$-file represented the diameter of the mesiobuccal root of the maxillary first molar. This file size was obtained by determination of the initial apical file after cervical flaring with LA Axxess burs. Kerekes and Tronstad (18) have stated that instrumentation of curved and narrowed canals up to sizes 25 or $30 \mathrm{~K}$-files do not provide an accurate apical cleaning. McSpadden (19) has postulated that curved canals should be enlarged with NiTi files up to a size 40 instrument. Although a definite criterion for apical instrumentation in curved canals has not yet been established, the literature has agreed that the minimal final diameter should correspond to a size $25 \mathrm{~K}$-file (20).

The parameter generally adopted for enlargement of the apical portion at the working length consists of determination of the initial apical file and instrumentation of this region using three file sizes greater than the first file that binds at the WL. The binding sensation is based on the operator's tactile sensitivity. However, this has been claimed to be an unreliable and empiric method for accomplishment of such an important step of the biomechanical preparation (10).

Taking into account that the major purposes of the endodontic therapy is the cleaning and shaping of root canals, and considering that the first shortcoming to be overcome is performing an accurate determination of the file from which on the canal should be instrumented, it is important that current concepts and techniques in Endodontics are reviewed to widen the scopes in root canal treatment and offer new perspectives and parameters that make these goals achievable.

According to the methodology proposed and based on the findings of this study, the following conclusions may be drawn: preflaring of the cervical and middle thirds improved the determination of the anatomical diameter at the working length; the type of instrument used for preflaring interfered with the determination of the initial apical file; canals preflared with LA Axxess burs showed the least discrepancy between initial file size and anatomical diameter, and therefore a more accurate binding of the files at the working length; two-by-two comparisons classified the preflaring techniques in decreasing order of discrepancy between the smallest canal diameter and the initial apical file diameter, as follows: no preflaring $>$ Gates-Glidden $=$ Orifice Opener $>$ Protaper $>$ LA Axxess.

\section{RESUMO}

Avaliou-se a influência do pré-alargamento cervical na determinação do instrumento apical inicial em raízes mésiovestibulares de molares superiores. Foram selecionados 50 primeiros molares superiores com grau de curvatura da raiz mésio-vestibular padronizado entre 10 e 15 graus. Concluída a cirurgia de acesso e remoção do tecido pulpar, determinou-se o comprimento de trabalho a $1 \mathrm{~mm}$ do ápice. Os dentes foram divididos aleatoriamente em 5 grupos $(n=10)$, de acordo com o tipo de alargamento realizado: Grupo 1: sem alargamento cervical; Grupo 2: brocas Gates-Glidden; Grupo 3: Orifice Opener; Grupo 4; ProTaper; Grupo 5: LA Axxess. Os canais foram explorados com lima do tipo $\mathrm{K}$ inserindo-se passivamente a lima 08 no comprimento de trabalho. A seguir, limas de maiores diâmetros foram sucessivamente introduzidas no canal radicular, até se obter a sensação de travamento no comprimento de trabalho. O diâmetro desse instrumento foi registrado, e este foi fixado em posição no canal com cianoacrilato de metila. Secções transversais realizadas no comprimento de trabalho foram observadas ao microscópio eletrônico de varredura e a discrepância entre o menor diâmetro do canal e o diâmetro do instrumento apical inicial foram calculados para cada amostra, por meio de um software. As médias de diferença entre esses diâmetros obtidas em cada grupo foram submetidas à análise estatística. A análise de variância indicou diferença estatisticamente significante entre os grupos $(\mathrm{p}<0,001)$. O teste complementar de Tukey evidenciou a maior discrepância para o grupo que não recebeu o préalargamento (média: 0,1543 mm $\pm 0,0216$ ). As brocas LA Axxess promoveram a menor diferença entre o diâmetro anatômico no comprimento de trabalho e o instrumento apical inicial (média: $0,026 \mathrm{~mm} \pm 0,0037)$. As brocas Gates-Glidden e os instrumentos Orifice Opener foram estatisticamente semelhantes $(p>0,05)$ (média: 0,1167 $\mathrm{mm} \pm 0,0231$ e 0,1313 $\mathrm{mm} \pm 0,0344$ respectivamente) O pré-alargamento realizado com instrumentos ProTaper evidenciaram a média de $0,0567 \mathrm{~mm}$ e desvio padrão 0,0354 para os valores de discrepância. Pode-se concluir que o pré-alargamento dos terços cervical e médio permitiu uma melhor determinação do instrumento apical inicial. O grupo no qual foram utilizados instrumentos LA Axxess refletiu com maior fidelidade o diâmetro anatômico no comprimento de trabalho em raízes mésio-vestibulares de primeiros molares. 


\section{REFERENCES}

1. Grossman LI, Oliet S, Del Río CE. Preparation of the root canal: equipment and technique for cleaning, shaping and irrigation. In: Endodontic Practice. Grossman LI, Oliet S, Del Río CE (Editors). 11th ed. Philadelphia: Lea \& Febiger; 1988. p. 179-227.

2. Ingle JI, Bakland LK, Peters DL, Buchanan LS. Endodontic cavity preparation. In: Endodontics. Ingle JI, Bakland LK (Editors). 5th ed. Malvern: Williams \& Wilkins; 1994. p. 92228.

3. Torabinejad M. Passive step-back technique. Oral Surg Oral Med Oral Pathol 1994;77:398-401.

4. Walton RE, Rivera EM. Cleaning and shaping. In: Principles and Practice of Endodontics. Walton RE, Torabinejad M (Editors). 2nd ed. Philadelphia: W.B. Saunders; 1996. p. 201233.

5. Souza RA, Ribeiro FC. Influência do preparo cervical na ampliação do canal. Rev. ABO Nac 2002;9:352-355.

6. Leeb J. Canal orifice enlargement as related to biomechanical preparation. J Endod 1983;9:463-470.

7. Philippas GG. Influence of occlusal wear and age on formation of dentin and size of pulp chamber. J Dent Res 1961;40:11861198.

8. Tan BT, Messer H. The effect of instrument type and preflaring on apical file size determination. Int Endod J 2002;35:752-758.

9. Contreras MAL, Zinman EH, Kaplan SK. Comparison of the first file that fits at the apex, before and after early flaring. J Endod 2001;27:113-116.
10. Wu MK, Barkis D, Roris A, Wesselink PR. Does the first file to bind correspond to the diameter of the canal in the apical region? Int Endod J 2002;35:264-267.

11. Pécora JD, Capelli A, Guerisoli DMZ, Spanó JCE, Estrela C. Influence of cervical preflaring on the apical file size determination. Int Endod J 2005;38:430-436.

12. Barroso JM, Guerisoli DMZ, Capelli A, Saquy, PC, Pécora JD. Influence of cervical preflaring on determination of apical file size in maxillary premolars: SEM analysis. Braz Dent J 2005; $16: 30-34$

13. Schneider S. A comparison of canal preparations in straight and curved root canals. Oral Surg Oral Med Oral Pathol 1971;32:271-275

14. Stabholtz A, Rotstein I, Torabinejad M. Effect of preflaring on tactile sense detection of the apical constriction. J. Endod 1995;21:92-94

15. Khan IU, Sobhi MB. Detecting the apical constriction in curved mandibular molar roots-preflared versus nonflared canals. J Ayub Med Coll Abbottabad 2003;15:47-49.

16. Ruddle CJ. The Protaper endodontic system: geometries, features and guidelines for use. Dent Today 2001;20:60-67.

17. Luiten DJ, Morgan LA, Baumgartner JC, Marshall JG. A comparison of four instrumentation techniques on apical canal transportation. J Endod 1995;21:26-32.

18. Kerekes K, Tronstad L. Morphometric observations on the root canals of human molars. J Endod 1977;3:114-118.

19. McSpadden JT. NiTiMatic system product instruction manual. Chattanooga: NiTi Co.; 1992.

20. Morgan LA, Montgomery S. An evaluation of the crowndown pressureless technique. J Endod 1985;11:203-211.

Accepted June 29, 2005 